\title{
'Send your books on active service': The books for troops scheme during the Second World War, 1939-1945
}

\author{
Archie L. Dick' \\ Department of Information Science, University of Pretoria, Pretoria, 0002, Republic of South Africa. \\ archie.dick@up.ac.za
}

Received: 15th September 2004

Revised:29th November 2004

\begin{abstract}
During the Second World War, the South African Library Association coordinated the Books for Troops Scheme that distributed thousands of books and magazines to soldiers in the Union Defence Force. The scheme presented the chance to demonstrate the democratic values of books and libraries, and to improve the social standing of the library profession. This article argues that personal squabbles, regional tensions, racialism and the regulation of reading by the Army Education Services prevented the South African Library Association from making a more forceful impact on the South African public.
\end{abstract}

Keywords: Army Education Service; Books for Troops; Second World War; South African Library Association; Union Defence Force.

\section{Introduction}

When General Jan Smuts' amendment to General Barry Hertzog's neutrality motion was carried by 80 votes to 67 to enter the Second World War as Great Britain's ally on 4 September 1939, South Africa was at war. But the price of loyalty to Britain and its Commonwealth allies and a stand against Nazi Germany was internal division among white South Africans. The United South African National Party (later the United Party) that had 'fused' the National and South African Parties in 1934 now lost most of its Afrikaner support. The bulk of Afrikaners (including Hertzog) rejected Smuts' decision and regrouped under the banner of Daniel F Malan's Purified National Party to become the Re-united National Party (Oakes 1989: 344-8).

Internally, the war therefore aimed at English-Afrikaner reconciliation and at winning all South Africans to the Allied cause. Raising troops for the Union Defence Force would, as a consequence, not be through coercion but through volunteers only. Black South Africans were also allowed to join the Union Defence Force (UDF) but not as armed combatants. Some were enthusiastic about the war, others were indifferent but most black volunteers grabbed the opportunity to learn new skills and earn a regular salary (Grundlingh 1986). The black or 'Non-European Army Services' (NEAS) comprised three corps, namely, the Cape Corps that consisted of 'Cape Coloureds', the Indian and Malay Corps, and the Native Military Corps. They were used as boot makers, drivers, trench-diggers, carpenters, cooks and stretcherbearers, but later also learned typing and clerical skills (Gleeson 1994: I I2).

The war presented a unique opportunity to build a truly South Africanist loyalty with a captive audience of $\mid 23$ |3| blacks, and 2 II 193 whites of which about $60 \%$ were Afrikaans speaking and $40 \%$ were English speaking (Official Year Book 1946: 20). It also offered a young South African library profession the chance to promote the democratic values of books and libraries. The Vice-President and leading spokesperson for the South African Library Association (SALA), Douglas $\mathrm{H}$ Varley, had in fact affirmed this role for books in a talk to the Association of University Women in 194I. He argued (Battle of the Books 1942: 97-8) that books were potent weapons of war because they were the embodiment of ideas, and that the function of books in a time of war was to brace the individual during his periods of inaction both for the onslaught of war and for the construction of peace at the end of the war. 'In the war of 1914', he continued, 'people read for solace. Now they read ... for the reaffirmation of their beliefs in the manner of life they are defending'. His reference was to defending the democratic way of life against Nazi fascism, and to the strategic role of books and libraries.

This article, however, elaborates views of a narrowed South Africanist loyalty (Cardo 2002; Dubow 2000), by focusing on the Books for Troops Scheme that was coordinated by the SALA from 1939 to 1945. The principal argument is that personal squabbles, regional tensions, racialism and the regulation of reading by the Army Education Services (AES) prevented the SALA from making a stronger impression on the South African public of the democratic values of books and libraries. Historical research in library and information studies should explain events and promote understanding, and this case study will show that wherever there are social forces to expand democratic access to books and information there are opposing social forces to restrict access.

Print culture serves many purposes during wartime that include amusement, information, training, rehabilitation, propaganda and preparation for post-war reconstruction. Soldiers and civilians engage in a range of reading activities, and

I. Archie Dick is professor of Information Science at the University of Pretoria 
book provision requires much time and effort but librarians often learn valuable lessons about themselves and the social significance of libraries (Kelly 2003; Loss 2003). The Books for Troops Scheme's dual military and public focus offered the SALA the chance to improve the social standing of the library profession.

\section{Origins and early work}

Book schemes for soldiers are nothing new and they are still found in modern conflict situations such as the Iraq war, for example (Gussow 2002; Triggs 2003). In So: th Africa, schemes to provide literature to troops before the Second World War had already been associated with the South African War from 1899 to 1902 (Guild of Loyal Women 1905), and with the First World War from 1914 to 1918 (Troops Literature Depot 1918). These schemes were organised largely by untrained volunteers, before the founding of the SALA in 1930. But with the opening of the Second World War in September 1939, English speaking white South Africans and librarians were soon following the examples found in Great Britain and beginning to replicate them locally (Turner 1939; Libraries for H.M. Forces 1940). On 19 October 1939, a newspaper article reported that W G Griffiths, a librarian from the Benoni Library (who later became a Major), and T Newby had started a book scheme (650 Gift Books for S.A. Troops 1939). They had received and distributed over four hundred books, including Afrikaans volumes, to camps in various parts of the country, and they anticipated the national adoption of their rapidly growing scheme.

The early war concerns of the SALA, however, were for increasing financial support from the Union Government to libraries. The SALA's Honorary Secretary, Matthew M Stirling, dispatched a letter to the Secretary for the Interior on 8 January 1940 that was based on a talk by Reginald F Kennedy of the Johannesburg Public Library, on the public library in time of war. Provision was requested for the inevitable increase in the public use of libraries for preserving civilian morale and supplying accurate and up-to-date information. The letter reminded government of an earlier Committee recommendation to give a 'strong lead' for Provinces to follow, and pointed out that $98 \%$ of the adult rural 'European' population was still denied library facilities. It concluded (Correspondence 1940) with the strong caution that 'An uncultivated and illiterate section of the population, such as permeates the Union, is not only a disgrace: it is a deadly danger in any democracy'.

At the third triennial general meeting of the SALA in Cape Town from 18 to 20 March 1940, subsequent motions from W G Griffiths for all libraries to act as receiving depots for books for 'soldiers, sailors and nurses' and from the SALA's President Charles Christie for increased financial support from the Union Government were carried (Report 1940). The SALA did not, however, play an active role in organising the collection of books for troops. Instead, local committees were formed, and the most prominent of them was the Cape Town Books for the Troops Committee (CTBTC) that met regularly from July 1940 in the Fairbridge Room of the South African Public Library (SAPL), in Cape Town. Several storerooms in the library were used for sorting, stamping, parceling, and distributing books and magazines. The chairman of the CTBTC was the SALA Vice-President Varley, who was also in charge of the SAPL. Other organizations that offered assistance to the CTBTC during the initial stages of its work included the South African Women's Auxiliary Unit, local Publishers, the City Tramways and the Boy Scouts Association.

By November 1940, there were 30000 books and twice as many magazines that had already been dealt with since July of that year, and Varley and the CTBTC began to attract public interest (Mr Douglas Varley 1940). These materials had been collected in more than 25 centres in the Western Province and sent by rail to the SAPL where they were sorted and distributed by voluntary helpers. Selection of the materials was according to their suitability for the troops. Unsuitable books were sent to hospitals and hostels or sold to raise funds for the committee. Most of the books received were works of fiction - thrillers, wild west and similar light material, and Varley (First Progress Report 1940) appealed for more serious fare, for monetary contributions to buy books, as well as for more Afrikaans books because of the 'high proportion of Afrikaans-speaking men on active service'. The books were distributed to local camps and batteries such as Wynberg, Simonstown, Walvis Bay, Oudtshoorn and Kimberley in the Cape Province. A large consignment was forwarded to Pretoria for onward conveyance to the front line in East Africa, and the CTBTC concentrated on pressing local demands.

In the Transvaal Province (now Gauteng), a Books for the Troops Scheme was formed in Pretoria, and met monthly at the State Library. Its Honorary Secretary was the librarian M W Whitely, and representatives of the Red Cross, the Rotary Society, and the Young Men's Christian Association (YMCA) assisted the scheme with its work. It presented its first report on the work of the main centre libraries in September 1940, in which it revealed an early concern to serve 'NonEuropean' training camps and naval vessels. The report identified the lack of books in Afrikaans and the problems of distributing the 69410 books and several thousands of magazines already collected, and indicated that a first consignment of I 800 books had left for troops already stationed in Kenya, Nairobi. Literature collected from the public was carefully checked for 'seditious material' before distribution to the troops (Summary of Report 1940). 
A succession of personal squabbles between Stirling and Kennedy contributed in June 1942 to the independent establishment of a 'Books for Troops Committee' in Johannesburg (BTCJ) that incorporated the earlier Pretoria-based scheme. The BTCJ had its own constitution and banking account, and included representation from the SALA, the YMCA and the UDF (SALA Books for Troops Funds 1942; for the purposes of this article, the BTC] refers to both schemes that operated in the Transvaal Province). In response to these developments, the SALA set up a liaison committee to oversee the entire country's activities regarding the Books for Troops movement. The YMCA was especially helpful with the establishment of camp libraries through its hut leaders. The YMCA also reported a great demand for books in African languages for 'Non-European troops' although there were views that requests for books in the vernacular were in fact isolated (Minute Book 1940-1945, 1941:35). This led to enquiries about titles and prices and street collections for funds to buy these books, which were sent to black troops in the UDF (Pretoria Books for the Troops Scheme 194I).

The BTCJ coordinated the various regional activities of Books for Troops centres based at public libraries in Durban, Port Elizabeth, Pietermaritzburg, Bloemfontein and East London (Peters 1945: 543). It received books 'in good numbers from the country districts' (City of Johannesburg 1943), and distributed most of its material to camps in the Transvaal Province but included Bloemfontein, Ladysmith and Cape Town. It also supplied troops in North Africa when they were transferred from Kenya to Egypt in May 194I, and by October of that year the BTC] had distributed 42797 books to South African divisions in these countries (SALA - YMCA Book Committee 194I). Books and magazines from the CTBTC and the BTCJ were usually distributed to the troops under the supervision of army padres and chaplains. Both the CTBTC and the BTCJ used the press, cinemas, the radio, business companies, municipalities and libraries to publicise their work and to appeal to the public. Following requests from Varley in the Cape and Christie in the Transvaal, the Minister of Posts and Telegraphs allowed free freightage of book parcels across the country if they were clearly marked 'books for the troops'. This rail concession led to the collection of many more books and magazines from the public.

\section{Regional tensions}

After a promising start, however, a number of developments in 194I set the tone and pattern for the Books for Troops Scheme for the rest of the war. On 23 May 1941, Varley tabled a two-part motion, namely:

I. that the SALA, having sponsored the collection and distribution of recreational literature to the Fighting Forces, now calls upon the Government to build on this foundation by providing and adequately maintaining properly organised library services in military camps and establishments throughout the Union, under the supervision of a trained librarian; and

2. that a deputation from the Council approach Major E G Malherbe, and with his cooperation seek an interview with the Defence Authorities to explain and enlarge upon the above proposal.

Varley argued that voluntary appeals for books, as had been the case in the First World War, brought in 'a good deal of trash' and that the scheme's success depended largely on the goodwill of volunteers. The time had come, he believed, for the Government to implement the provision of libraries 'according to a worked-out plan similar to that in England (my emphasis), and in conjunction with the Army Education Services (New Matter 194I). Varley (1942: I), who had arrived in South Africa from England in March 1938, expressed concern that South African librarians should not lag behind their colleagues in other parts of the world regarding the supply to troops of books for information as distinct from relaxation.

The keenness to approach Major Ernst G Malherbe was driven by his interest in library work and his considerable weight with the Government. Malherbe was head of the Army Education Services (AES) and had also just been appointed chairman of the Transvaal Library Advisory Committee on 8 May 194I. Varley maintained that the SALA, through its practical demonstration to the public of dealing with immediate problems, should now make the Association's weight felt in high places. But when this motion came up for voting on 24 July 194I, a motion from the SALA's Transvaal branch was suddenly added, namely that:

I. on the request of the Transvaal branch the Council urge the Government to provide properly selected and

properly controlled libraries for men and women on active service (Libraries for the Army 194I).

There was no significant difference between the two motions, and they surfaced tensions between the Transvaal and Cape branches. Some sources of this ongoing regional conflict were claims of a strong British influence in the Cape, that two thirds of the Union's libraries were in the Cape Province, poor communication between north and south, an ongoing debate about the recognition of the University of Cape Town's diploma in librarianship, and the editorship of the professional journal, South African libraries. The second motion was probably added because a sub-committee of the Transvaal branch had already produced a concrete plan called the 'Scheme for Soldiers' Libraries' on 7 June 194I. Phyllis M Speight, whose talk on 5 June 194I to the Transvaal branch led to the second motion, had chaired this sub-committee. This meant that either the Transvaal branch was at odds with Varley and the Cape branch for petty provincial reasons, or that there was a genuine attempt by the Transvaal branch to keep control of the Books for Troops Scheme out of the 
hands of Malherbe and the AES. There was the fear that the AES would be mainly concerned with their own courses and activities, and not take care of 'all the reading needs of the men' (Scheme for Soldiers' Libraries 1941: 3).

Varley was ambivalent about the Transvaal branch's scheme. This is clear from his lukewarm support, and his unquestionable influence as SALA Vice-President in withdrawing the request to send the plan to the Union Government from the SALA Council agenda (Second Progress Report 194I). The Council's recommendation that Speight instead draft a letter to the Civil Re-employment Board about the lack of facilities for purposeful reading material among members of the military and the need for adequate provision for rehabilitation was a red herring, if not a cruel joke.

Speight's scheme, however, was itself cynical, dogmatic and unrealistic. Its book committee would be headquartered in Pretoria, and included a full-time Scheme Organiser, the State Librarian (in Pretoria) and the Johannesburg City Librarian. There would be no representative from the Cape or other provinces. The book committee would, moreover, be 'responsible for the book selection and ordering for the whole scheme' (original emphasis). Suitability of books was a matter to be decided between the 'Books for the Troops' Main Centres and the Scheme Organiser. Finally, the cost of the scheme was prohibitive in the circumstances, and it expected salaries for 2 organisers, 6 regional officers, 20 camp librarians, 10 clerical workers, money for books, buildings, equipment and stationery, totaling over 18000 British pounds per annum (Scheme for Soldiers' Libraries 194I: 4).

Varley instead sought a library scheme parallel with Malherbe's AES because he realised that the public could not provide the kinds of educational books needed by the troops on a sustained basis. Soldiers whose careers were interrupted, those who wanted to keep in touch with their civilian occupations, and others with a university education required books of a more serious and vocational nature (Second Progress Report 194I). He believed that the AES could fulfill these needs but he anticipated that several qualified librarians already serving in the UDF would administer this service. However, this did not turn out quite as Varley had expected. The UDF did take responsibility for the work of the CTBTC and the BTC], and acted as the sole distributing centre for books (Malherbe 1981: 220). The scheme would, however, be administered under an Army Information Scheme in the AES by Information Officers (first called Education Officers), who were put through an AES programme prepared by Malherbe and Leo Marquard.

\section{Information Officers and regulated reading}

The CTBTC and the BTC] continued to collect and distribute books to their agreed target areas, but the entire Books for Troops Scheme was now directed by the Information Officers, under a senior Information Officer. The syllabus of the educational programme for Information Officers aimed at equipping soldiers to defend democracy and preparing citizensoldiers to build a better democracy once the threat of fascism had been removed (Cardo 2002). Their preparation consisted of month long courses of lectures on social, political and economic matters of local and international importance, and the internal dynamics of military organization (Malherbe 1981: 218-20). An Army Education Handbook was later produced to assist with their instruction. After completion of these courses, the Information Officers were posted to units in North Africa or in the Union. In lectures, discussions and debates, the Information Officers were expected to promote a 'democratic way of life' by teaching troops the recognition and use of facts, and the cooperative sharing of information and views as the basis of democratic government.

Information Officers' duties included the distribution of periodical literature and the organization of library services for troops (Army Education Handbook 1943: 5; 159). In this arrangement, reading was gradually regulated towards serving the educational objectives of Information Officers, and constrained the free choice of general reading material. Information Officers, which later included women as Welfare Information Officers, put their stamp on their educational work, but Malherbe and Marquard influenced their political outlook. Malherbe was strongly in favour of Anglo-Afrikaner reconciliation within a broader white South Africanism. He was especially opposed to the growing Afrikaner nationalist republicanism and its Nazi sympathies. Marquard's South Africanist perspective instead sought to educate Information Officers in democratic citizenship so that troops would consider also the accommodation of black South Africans in a post-war political dispensation. Their views, however, were not sharply distinguished from each other and they interacted and reinforced each other (Cardo 2002: 16I-2).

Importantly, this led to the use of black lecturers such as Z K Matthews and R V Selope Thema in the courses for Information Officers, and to visits to the 'Bantu Social Centre' and townships in Johannesburg. The Army Education Handbook (1943: 137-58) also included a full chapter on the origins and policies relating to 'Non-Europeans in South Africa'. A subsequent survey covering a representative sample of 7000 white soldiers showed that $47 \%$ believed that blacks should be given chances to get better jobs and earn more money, and $42 \%$ said that blacks should be given more political rights (Cardo 2002: 167; Malherbe 1981: 250-2).

But it is uncertain and probably unlikely that black troops themselves attended the lectures presented by Information Officers. Practical military arrangements prevented this, and the 'dilution' policy in the latter part of 194I that was 
supposed to include black troops in non-combatant posts in white units to release white incumbents for combatant duties met with racial prejudice (Gleeson 1994: 138; Vane 1943). Social clubs and recreation centres, which housed the library collections from the Books for Troops Scheme, were also separated along racial lines (Ponsford n.d.: 25-32). The changing political and intellectual perspectives of blacks as potential South African citizens did not translate into actual acceptance of them by white soldiers (Knoetze 1945: 53). It was a matter of future political representation but present segregation.

There were, however, useful efforts by the AES to teach black troops to read and write and improve their general education (See Figure I). Officers and non-commissioned officers were trained at special courses at a school in Rietfontein in Pretoria to teach literacy classes to black troops, and Malherbe promised that Information Officers would assist (NCOs School Correspondence 1943). In North Africa and the Middle East, literacy classes were established by the AES whenever possible, but lessons were interrupted by the conditions of war, and fluctuating numbers complicated steady progress (Knoetze 1945: 53-5; Ponsford n.d.: 40). But there were successful results in some units and many soldiers learned to read and sign their names, which were useful attributes in the army. More black drivers were produced in this way because they could read road signs, maps and street names.

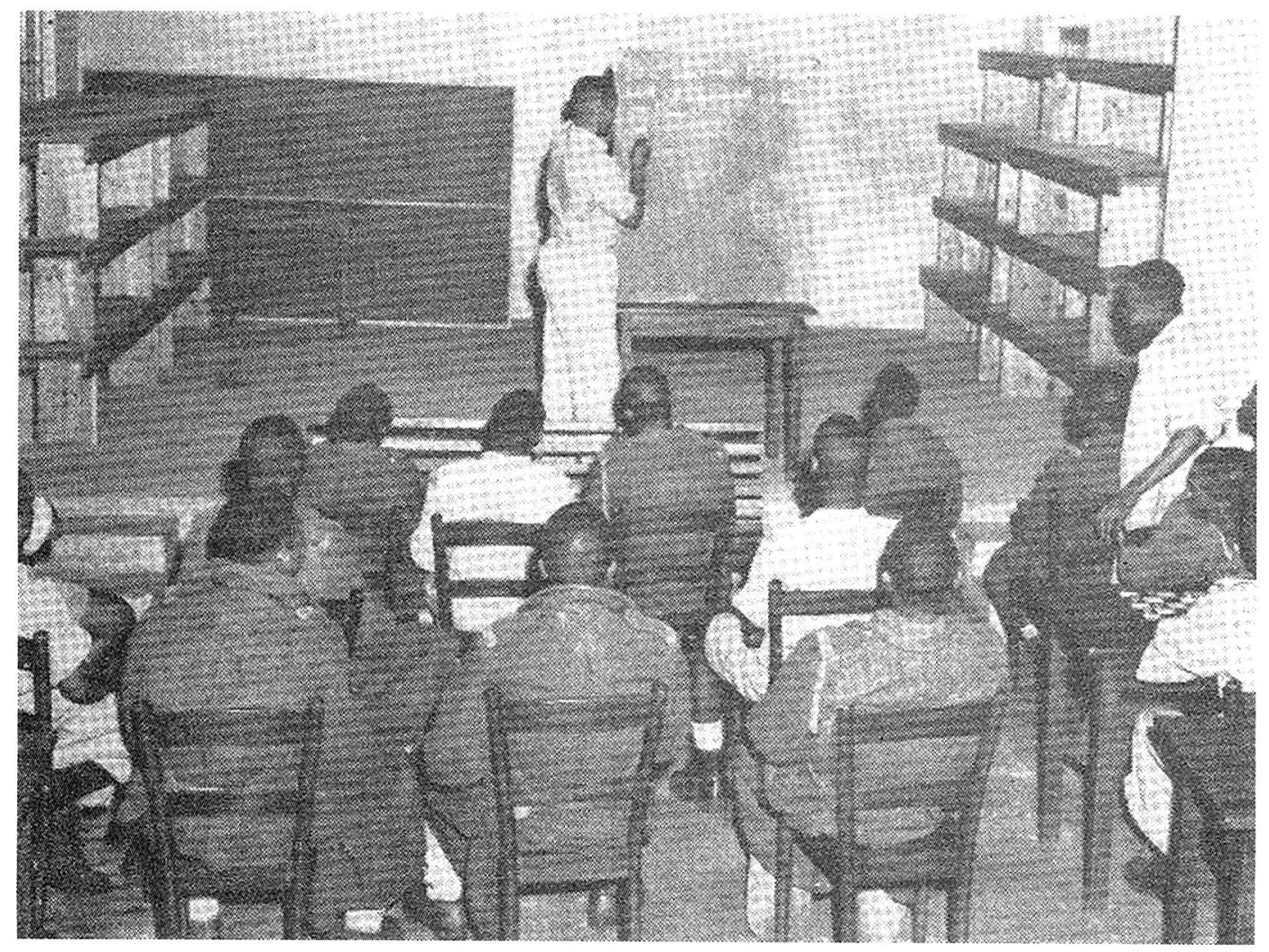

Figure I School for Black troops. Source: Ponsford, T.R. n.d. War record of Union Defence Force Institutes (Y.M.C.A.-Toc H), 1939-1946, p. 88.

There were also a number of libraries set up in the camps for black troops, and the appeals to the public were primarily for Christian literature. Bibles, hymnals and prayer books were sought, as well as books dealing with hygiene and first aid and other general reading and educational works, especially in the vernacular (Literature for Native troops 1942: 43-4). For Blacks, it would appear that books and magazines were intended more for morality than for morale. The collection of these books and magazines from the public were coordinated by the CTBTC and the BTCJ, which claimed a policy of 'equitable treatment for European and Non-European troops' (Minute Book 1940-1945, 1942: 49). Instructional pamphlets on subjects like farming were also specially prepared and distributed to black troops.

There were also social class and military factors that impacted on both black and white troops. Rigid army hierarchy and class divisions diluted the democratic potential of the scheme in a number of ways. Military Departmental libraries, for example, were restricted to officers and personnel of higher rank, and there is no evidence of their cooperation with the CTBTC or the BTCJ, or of an attempt to serve low-ranking fighting forces. These Defence libraries were, moreover, well financed and fully stocked with military books, fiction and periodicals from local and international publishers (Defence H.Q. Library 1942). Their cooperation would have boosted the scale, quality and legitimacy of the scheme, and 
improved the distribution and collection of books and magazines that were usually lost or misplaced when troops moved from one camp to another.

Multiple military ranks further complicated the work of the Division of Information Officers, which was routinely organised through the Commanding Officer, Senior Information Officers, and Brigadier Information Officers. The several levels in the chain of command limited the benefits of the reading service to the troops. The democratic ideals of the Books for Troops Scheme were compromised, moreover, when Information Officers also began to act as intelligence officers for Malherbe, who had become Head of Military Intelligence, and entrusted with the censorship of soldiers' letters (Malherbe 1981: 222).

\section{Growth and challenges}

Despite these constraints, thousands of books and magazines continued to be distributed to troops in the UDF. By September 1941, over 175000 books and three times as many magazines had been collected throughout South Africa and distributed to the fighting forces. Varley renewed his appeal for good light and serious fiction, history, biography and travel, and called for French and Dutch language literature in addition to those in English and Afrikaans. He reported that the CTBTC had deait with 60000 books and 180000 magazines from 25 centres in the Western Province and distributed them to several camps in the region.

Interestingly, the Koffiefontein Internment camp, which confined anti-war and pro-Nazi Afrikaners like apartheid era Prime Minister John B Vorster and his Head of security police Hendrik van den Bergh, also received consignments of books from the CTBTC (Second Progress Report 194I). By contrast, a Committee for the Relief of Anti-Nazi Internees supplied literature to anti-war and anti-Nazi Trotskyists like Max Gordon, who was interned at Ganspan Internment camp (Drew 2002: 232-3). South African troops that had been captured and detained as prisoners-of-war in Italian and German concentration camps continued to receive books through the South African Red Cross Society. A very strict censorship policy was applied to these consignments, and all books in Afrikaans as well as those dealing with agriculture, scouting, chemistry, and pharmacy were rejected as unsuitable, as were anti-Italian, anti-German and all books by Jewish authors (Books for Prisoners-Of-War 1942).

South African prisoners-of-war also cooperated with fellow detainees to produce camp newspapers such as The Observer, The Griff - South African supplement, The Outcrop and African Mirror to stay abreast of events in South Africa (Leigh 1992:72-90). Some resourceful prisoners-of-war bribed guards and officials to increase the numbers and kinds of books and magazines, and one even escaped with his magazines and hid them with an Italian family (Longden 1959:9).

The BTCJ allocated a substantial amount of money to buying Afrikaans books and subscribed to such magazines and journals as Huisgenoot and Kort en Goed, while it received 1000 copies of each issue of Naweek free-of- charge (SALA YMCA Book Committee 194I). By September 1942, the numbers increased to over 200000 books, and magazines had passed the half million mark countrywide. The Federation of Afrikaans Cultural Organisations (FAK) cooperated with the scheme through regular public appeals for books in Afrikaans. The CTBTC decided to broaden its membership in order to streamline the work of collecting books and funds, to prevent overlapping of various organizations, and to improve publicity (Third Progress Report 1942). This new and larger committee included representatives from the Cape branch of the SALA, the Merchant Seamen's Welcome Club, the Navy league, the Navy Wartime Workers, the Seamen's Institute, the Victoria League, the YMCA, the South African Red Cross, the Rotary Club and the South African Gifts and Comforts committee. By August 1944 this committee had grown to 20 members.

The more widely representative committee brought in additional funds and fresh ideas on improving publicity. A constitution was adopted in October 1942 so that an application to the Cape Town city council for a proposed street collection would be possible. Varley was re-elected as chairman of this new committee (Special meeting 1942). The CTBTC invited a representative from the Navy League of South Africa to join the committee, and consolidated its work that had already included visiting warships, hospital ships and the naval forces. Fear of a Japanese invasion in June 1942 had led to intensified sea patrols of the coast line and reinforcement of defences at Union ports (Official Year Book 1946: 9). The CTBTC accordingly expanded its name to the Cape Town Books for Troops and Ships Committee. Reading matter was so valued at sea that when ships met in mid-ocean there was often an exchange of books between them (Servicemen still need books 1945).

A special 'Books for Troops' week in cooperation with the Kimberley Books for Troops Committee and a book drive arranged by the Boy Scouts' Association, raised thousands more books and magazines (Fourth Progress Report 1944). The Anti-Waste campaign also donated books that were still found useful, and many worn books were mended and 'sent into active service'. The CTBTC's work was arranged more systematically and carried out with renewed energy following the appointment of an Organising Secretary, Mrs D C J Jongens, who began to issue monthly and quarterly progress reports in 1943. Regular monetary gifts were arriving from branches of the organizations represented on the 
committee, a mobile library was introduced that improved service to troops in rural areas, and assistance was arranged to manage the Royal Naval War library. In October 1943, the CTBTC was officially registered as an approved charitable War Funds organization, which facilitated street collections.

There was also cooperation and regular correspondence with the BTCJ, which requested permission to use the publicity material of the CTBTC. Publicity posters were produced with the headline message: 'Banish Boredom. Books Are Weapons - Make Them Fight'. The posters went on to explain that boredom is the second greatest enemy in war and that it needs to be fought with books. The public was advised on what to send and how to send it. The CTBTC also created the 'Fighting Book' (later called the Fighting Man) symbol that was distributed to branches and centres throughout the Union, and became the standard identification for the Books for Troops Scheme countrywide. This symbol was also reproduced in the form of small stickers that could be used on official correspondence (See Figure 2).

Innovative ways of collecting books included Red Cross bins on railway stations, and books were distributed by adding them to 'glory bags' (parcels with gifts and comforts like socks, chewing gum and biltong) sent out monthly to troops, and supplying Soldiers' clubs with small collections. Funds were raised from special concerts and theatre productions, and the CTBTC began to show a consistent credit balance. The largest publicity event for the Books for Troops Scheme was its participation in the Liberty Cavalcade in Cape Town in April 1944. The CTBTC provided a stall in the 'Hall of Books', and the BTCJ sent down its Mobile library from Johannesburg for the event. The stall was decorated and advertisement slogans were posted inside the Hall of Books. Ten thousand leaflets were printed for distribution at the Cavalcade, and shifts were arranged to staff the stall (Minutes of special meeting 1944).

The BTCJ also expanded its service during 1943 and appealed to the public for a light panel van or delivery van to help distribute books and magazines to military hospitals, including Baragwanath and Cottesloe, in Johannesburg. Nineteen well-organised libraries were Figure 2 National symbol for the Books for Troops Scheme. already operating in the Middle East and book boxes of Source: Books for Troops and Ships Committee collection, National 250 books per box were circulated from unit to unit and Library of South Africa manuscripts collection, Cape Town. even sent to the front lines, where their transport priority ranked third after food and ammunition (See Figure 3). The BTCJ appealed to the public for pocket editions of good books, which did not need much packing space and could be carried by mobile units. A book drive - the 'Mile of Books' brought in about 24000 books and street collection boxes provided about I 400 books per month (Books for the Troops 1944: 75). Prizes such as an oil painting by J de Leeuw or 'a year's subscription to Anstey's library' were used as incentives to encourage the public to donate books (More books for Troops needed 1943). By July 1943, over 600000 books and many more magazines had been sent to South African troops from the centres at South African libraries (S.A. Libraries 1943).

More money was spent by the BTCJ on purchasing Afrikaans than English titles, and between five to ten percent of the book budget was used to buy books in the vernacular for black troops. The service to black troops in North Africa improved considerably after the Christian Council of South Africa spent more than 400 British pounds on religious and educational books, and established about 20 camp libraries at which 39 black YMCA secretaries and visiting chaplains supervised the distribution of books and illustrated magazines. In the Union, 104 YMCA secretaries supervised the distribution of books in camps for black troops (Circulating Library 1943). In the white camps, collaboration with the Army Education Services increased. The emphasis was strongly on educational and textbooks for study, and Information Officers had taken over the distribution of all books and magazines completely by 1943.

Anticipating the usefulness of books to support the work of the Information Officers was complicated by the different lectures they presented. And while the Books for Troops Scheme supplied textbooks to support the formal lectures by Information Officers on topics such as Afrikaans, French, bookkeeping and shorthand, it was found that only about five to ten percent of the troops was actually interested in furthering their education. Popular literature was claimed to be far 
more effective than vocational books for maintaining morale. But there were examples of the benefits of vocational books to troops, as in the case of a butcher who had lost an arm and a leg and since he could not return to his shop, decided to qualify as an abattoir inspector (More books for Troops needed 1943). Some prisoners-of-war, moreover, used the opportunity to study further at camp schools and by correspondence, and achieved prominent positions after the war (Leigh 1992: 91-9).

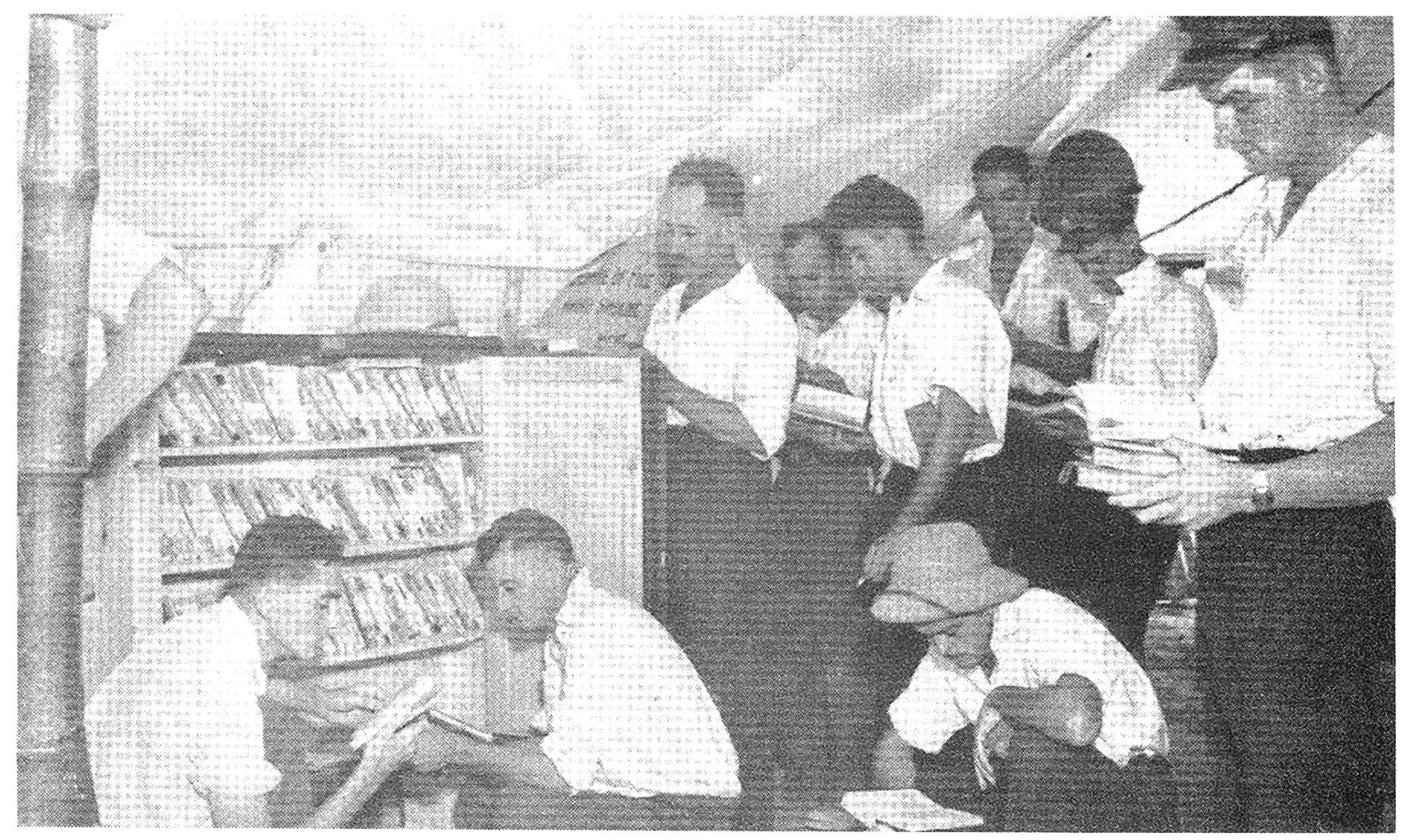

Figure 3 Camp hospital library. Source: Ponsford, T.R. n.d. War record of Union Defence Force Institutes (Y.M.C.A.-Toc H), 1939-1946, p. 40.

The Books for Troops Committees could not, however, obtain accurate and full information on their work. It proved frustrating, for example, to ascertain directly from troops what their reading tastes were or what kinds of books they really wanted. The Organising Secretary of the CTBTC, Mrs Jongens called the situation 'hopeless' because Senior Information Officers refused to or could not supply detailed lists of units or itineraries of mobile vans, for security reasons (Letter from Frylinck 1944). Some feedback was, however, provided through addresses to the Books for Troops Committees during 1943 by Major M H Eddy. He (Address Given 1943) indicated that troops showed their appreciation for the scheme by handing in books (on a 'book for book' basis) that they had personally received from relatives and friends, which increased the number of books available.

And a steady stream of letters of appreciation from troops strengthened the committees' resolve to continue their work (Correspondence-General). They were supported by a number of dedicated volunteers who helped with office work, book mending, sorting, making posters, painting slogans, street collections and other routine work. Through liaison persons, the CTBTC became more widely known and this resulted in a greater demand for books. In April 1944, Varley resigned as chairman because of his workload, and the Vice-chairman, Ms Doris M Syfret replaced him. She was reelected to serve until the committee disbanded in October 1945.

\section{Winding down}

As the end of the war and the prospects of a long process of demobilisation approached, there was an increasing demand from camps in North Africa and Europe for educational books and fiction, and especially for magazines. Light reading matter was needed especially to fight boredom as troops waited in transit camps before returning to South Africa (Books for Troops 1945; Ponsford n.d.: 218). At the same time, all the committees were running low on stocks (Big demand for books by troops 1945). Public appeals and the use of book mending parties could not meet the demand. The CTBTC introduced the idea of requesting the Prime Minister, General Smuts, to make a public radio appeal in the same way that the English Prime Minister, Winston Churchill, had. 
The radio appeal by Smuts on 16 March 1945 was the result of much correspondence with the Prime Minister's office, and of close cooperation between the CTBTC and the BTCJ (UDF's need of books 1945). Smuts appealed for all kinds of books and the results were immediate. Committees showed a surplus of books for the first time. Posters were used to keep alive the public interest in the Prime Minister's appeal, and some members of the CTBTC were invited to a morning tea-party given at Groote Schuur by the Prime Minister's wife, Mrs Smuts, where they publicised the work of the Books for Troops Scheme among the Cabinet ministers wives (Progress Report 1945).

The committees around the country began to wind down their activities after the war ended in May 1945, but there was still much work to be done as demands for literature poured in from camps both in the Union and abroad. These demands were readily and competently met by the committees, which had by then developed efficient methods for supplying literature to the troops (See Figure 4). The CTBTC held its last meeting on 19 October 1945, with a request from Varley that the committee minutes and other records should be handed over to the SAPL for safekeeping. Surplus funds were distributed to the South African Library for the Blind in Grahamstown and other smaller libraries while the surplus books were donated to the Pollsmoor ex-servicemen's centre. The BTC] continued for some time longer to meet the steady demand for books by troops in demobilisation camps outside the Union, and it held its $55^{\text {th }}$ and final meeting on I March 1946. It donated its surplus books to the Wonderboom Government village, to ex-soldiers' industries in Pretoria, and to a branch of the University of South Africa in the black township of Atteridgeville, outside Pretoria (Books for Troops closing down 1946).

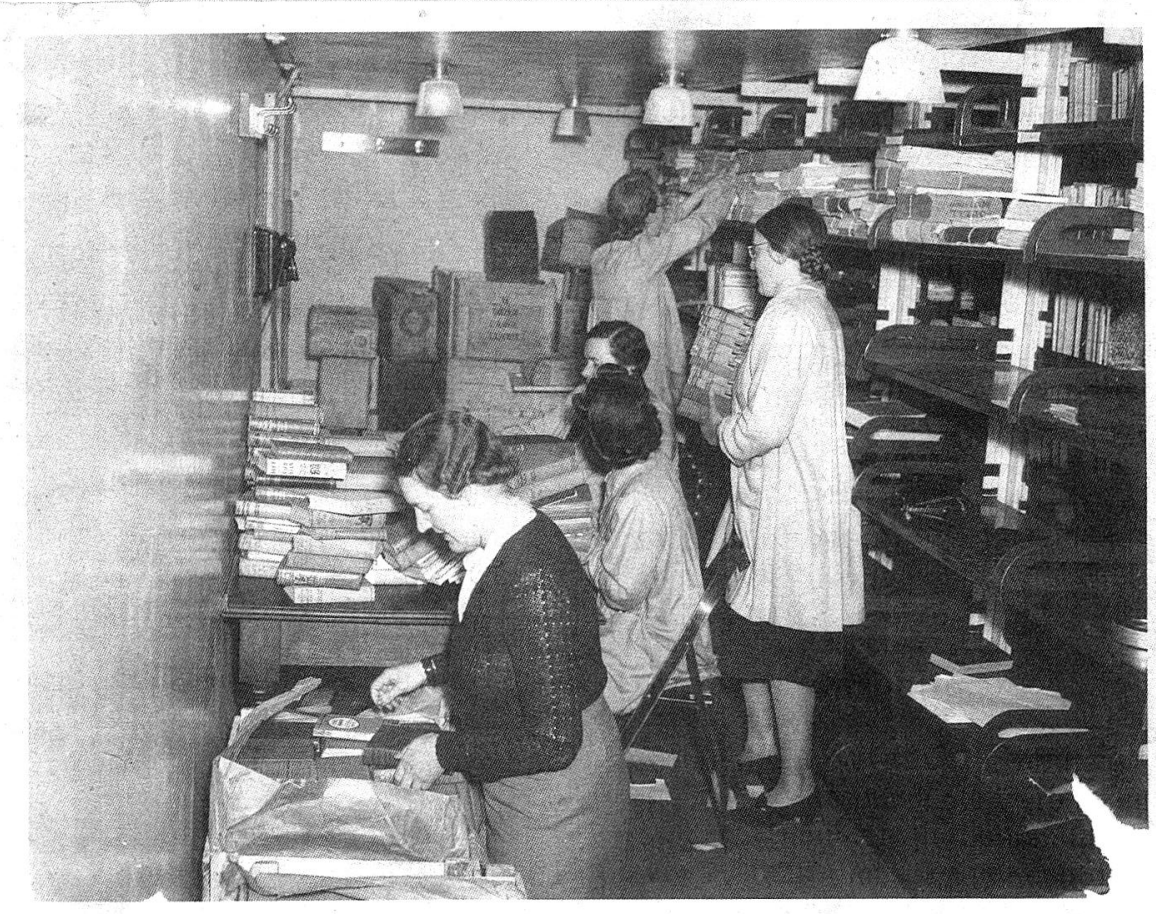

Figure 4 Sorting and packing in the Johannesburg Public Library. Source: Books for Troops Records of the Johannesburg Centre, 1940-1945, Johannesburg Public Library, Strange collection, Johannesburg.

Although the actual numbers of books dispatched to South African forces by the Books for Troops Scheme during the Second World War are uncertain, it is claimed that more than a million books and several million magazines had been distributed (Pretoria Books for Troops centre 1946). In spite of the attempts by Information Officers of the AES to guide the reading of troops strongly towards educational material, the letters of appreciation from troops themselves suggested the desire for as much fiction as possible. These included westerns, detective stories, travel, and sea adventures. Troops also read general works on politics, economics, history, philosophy, religion, poetry, art, music and technical subjects (Peters 1945: 544).

The Books for Troops Scheme provided both an insight into the reading tastes of the troops and the private collections of the general public. One commentator (Bressler 1943: 19) was surprised to discover among the books collected from the public some valuable works and early editions of George Bernard Shaw, Alexander Dumas, William Shakespeare, Joseph Priestly, George Eliot, Joseph Conrad, Anthony Trollope, Charles Dickens, Arthur Conan Doyle and William Thackeray. Some works like Eliot's 1859 edition of Adam Bede and Trollope's I882 three volume edition of Mr 
Scarborough's Family, he believed, could fetch high prices at a Sotheby's auction in London. There was also expensive works of non-fiction in the collection.

\section{Conclusion}

Although the SALA coordinated the Books for Troops Scheme, it was implemented and controlled by the AES. Soldiers' reading was also regulated to support the work of Information Officers to promote a 'democratic way of life' in post-war South Africa. In the end, however, the impact of the AES and the Information Officers was limited, and the Books for Troops Scheme failed to achieve an unassailable public perception of the democratic value of books and libraries. Librarians, for example, hoped that most of the troops would become members of the public libraries after the war (City of Johannesburg 1943:7). But the 220 Information Officers could not adequately serve an army of over 330000 soldiers, whose constant movement disrupted educational and library work. The liberal hopes of Malherbe and Marquard failed because the AES' democratic vision did not reflect broader white South African society at the time, and because educational and information schemes can never simply deliver or reproduce progressive ideals.

It is debatable too whether democracy could be successfully learned in a hierarchical military setting, or whether democracy could have been learned at all when so many of the troops were effectively excluded from full participation because of their colour. Post-war discrimination was felt immediately in May 1945 when the government issued cash and clothing allowances of 5 pounds and 25 pounds respectively for white discharged soldiers, 3 pounds and 15 pounds for 'Coloureds', and 2 pounds and a khaki suit worth 2 pounds for 'Natives' (Oakes 1989: 352). The regulation of the troops' reading contradicted the true democratic potential of books and libraries by restricting choice and guiding reading in given directions. This is probably true for syllabus-based reading in general, and underscores the advantages of the freedom of choice that libraries offer readers. The SALA sacrificed this democratic advantage when it requested the UDF's assistance.

Whether the SALA by itself would have achieved a significant public perception of the democratic values of books and libraries through direct interaction with the troops, is also doubtful. The SALA in the 1940s was characterized by internal squabbling, petty provincialism, and an 'ambivalent liberalism' (Clark 2004) that ensured that library services to black South Africans in the Union remained segregated and unequal. In Pretoria, for example, there was no library provision for blacks (Mokgatle 197I: 198). And in a submission to a Committee of Enquiry into adult education during the war, the SALA expressed its own ambitions to regulate reading through a comprehensive system of 'readers' advisers' (Adult Education 1945: 88). But through the work and support of the Books for Troops Scheme, however, many black soldiers began to read and write for the first time and to discover the joys and pleasures of reading, and many white troops learned that an inclusive South African national identity was possible.

This article shows that historical research in library and information studies need not merely be empirical and descriptive. It can and should also be explanatory, and promote understanding. In this case, the democratic idea of expanding access to books and information through an education and information scheme was undermined by a historically unequal political and socio-economic order. The scheme bore all the features of the 'old' South African society, and shows how class and colour mediated access to information already in the years before apartheid. It is in grasping the historical insight of a double dynamic of conflicting social forces to expand and to restrict access that information professionals can better respond to contemporary projects to promote access to information.

\section{References}

Address Given to "Books for Troops" Committee by Major M. H. Eddy, Second-in-Command U.D.FI. Mideast on Friday, 19th February 1943. Books for Troops Records of the Johannesburg Centre, 1940-1945, Johannesburg Public Library, Strange collection (hereafter JPL Strange), Johannesburg, File S/Store/Q 027.65.

Adult Education in South Africa: being a report by a committee of enquiry appointed by the Minister of Education. 1945. Pretoria: Government Printer.

Army Education handbook. 1943. Pretoria. In Unisa Archives (hereafter UA), Pretoria, Private papers, O.A. Oosthuizen collection.

Battle of the books. 1942. South African libraries, 9(3): 97-8.

Big demand for books by troops. 1945. 294000 sent from city; stocks now very low. Books for Troops, South African National Defence Force Documentation Centre (hereafter SANDF Doc), Pretoria, UWH, Box 268.

Books for Prisoners-Of-War, 10 June 1942. JPL Strange, File S/Store/Q 027.65.

Books for Troops: Chairman's Annual Report for 1944. Johannesburg, I $5^{\text {th }}$ January 1945. JPL Strange, File S/Store/Q 027.65.

Books for troops closing down. Rand daily mail, 15 April 1946. SANDF Doc, UWH, Box 268.

Books for the Troops Johannesburg Committee. 1944. South African libraries, I I (4): 75.

Bressler, R. 1943. Some surprising books have been 'sent into battle' with our forces. Outspan, 33(856): 19.

Cardo, M. 2002. 'Fighting a worse imperialism': White South African loyalism and the Army Education Services (AES) during the Second World War. South African historical journal, 46: I4I-I74. 
Circulating library for Rand military hospitals; move by Books for Troops Organisation. Star, 23 February 1943. Books for Troops, SANDF Doc, UWH, Box 268.

City of Johannesburg Public Library Annual Report of the Librarian of the year ended 30th June, 1943. [Loose leaf document in Unisa compactus periodicals section].

Clark, P.G. 2004. 'Better libraries for everyone': the development of library services in the Western Cape in the 1940s. Innovation: appropriate librarianship and information work in Southern Africa, 28: 22-30.

Correspondence-General. Books for Troops and Ships Committee collection. Cape Town, National Library of South Africa manuscripts collection (hereafter NLSA manuscripts), Cape Town, File MSB 7I/I/I0; this file contains hundreds of letters of appreciation from soldiers.

Correspondence with Secretary for the Interior. 1940. South African libraries, 7(4): 175-6.

Defence H.Q. Library. 1942. SANDF Doc, File CGS/GP2, Box 286.

Drew, A. 2002. Discordant comrades: identities and loyalties on the South African left. Pretoria: Unisa Press.

Dubow, S. 2000. Scientism, social research and the limits of 'South Africanism': the case of Ernst Gideon Malherbe. In Science and society in Southern Africa, edited by S. Dubow. Manchester: Manchester University Press.

First Progress Report. Books for the Troops. 2 I November 1940. NLSA manuscripts, File MSB 71/1/7.

Fourth Progress Report. 1944. [Cape] Books for Troops and Ships Committee. South African libraries, I I (3): 57-8.

Gleeson, I. 1994. The unknown force: Black, Indian and Coloured soldiers through two world wars. Rivonia: Ashanti Publishing.

Grundlingh, L. 1986. The participation of South African blacks in the Second World War. D.Litt et Phil thesis. Johannesburg: Rand Afrikaans University.

Guild of Loyal Women. 1905. Work in the Suburbs. Register and Minute Book - Executive Committee, 1903-1906. Cape Town Archives Depot, File A 333.

Gussow, M. 2002. Literature re-enlists in the military. New York times, II July 2002, 152(52295): I.

Kelly, M.S. 2003. Revisiting C.H. Milam's What libraries learned from the war and rediscovering the library faith. Libraries and culture, 38(4): 378-388.

Knoetze, J.C. 1945. Historical survey of the Non-European Army Services outside the Union of South Africa. SANDF Doc, UWH, Box 128.

Leigh, M. 1992. Captives courageous: South African prisoners of war, world war II. Johannesburg: Ashanti Publishing.

Letter from Captain Frylink to Organising Secretary, 22 May 1944. NLSA manuscripts, File MSB 71/1/10.

Libraries for the army. 24 July 194I. Circular no. 45. SALA Council agenda and minutes, 194I-1942. UA, SAILIS Archives, File 2/ $1 / 7$.

Libraries for H.M. Forces. 1940. Library Association record, 42(2): 44-5.

Literature for Native troops. 1942. South African libraries, 10(2): 43-4.

Longden, H.W.D. 1958. A P.O.W. camp library. The Cape librarian, December, I(I4):8-9.

Loss, C.P. 2003. Reading between enemy lines: Armed Services editions and World War II. Journal of military history, 67(3): $8 I I-34$.

Malherbe, E.G. 198।. Never a dull moment. Cape Town: Timmins Publishers; pages 2/8-219 provides a list of the names of the lecturers and the topics of study for Information Officers, as well as their post-war occupations.

Minute Book of the Books for Troops Johannesburg Centre, 1940-1945. JPL Strange, File S/Store/Q 027.65.

Minutes of special meeting held in Fairbridge library. 17 March 1944. NLSA manuscripts, File MSB/7 I/I/7.

Mokgatle, N. 197I. The autobiography of an unknown South African. Parklands: AD Donker.

More books for troops needed: special drive this month. The Star, 3 November 1943.

Mr Douglas Varley. 1940. Forum, 3(36): 2.

NCOs School Correspondence. 1943. SANDF Doc, AG (W), Box 20.

New Matter: motion by the Vice-President. 23 May 194I. Circular no. 42.

SALA Council agenda and minutes, 194I-1942. UA, SAILIS Archives, File 2/I/7.

Oakes, D. 1989. Illustrated history of South Africa: the real story. Cape Town: Reader's Digest. Second edition.

Official Year Book of the Union of South Africa and of Basutoland, Bechuanaland- Protectorate and Swaziland. 1946, no. 26, Chapter 29, The Union of South Africa and the war. Pretoria: Government Printer.

Peters, F.A. 1945. There's a Springbok waiting for that book! Nongqai, 36(5): 543-4.

Ponsford, T.R. n.d. War record of Union Defence Force Institutes (Y.M.C.A.-Toc H), 1939-1946. Cape Town: Hortors.

Pretoria books for troops centre to close. Rand daily mail, 2 April 1946. SANDF Doc, UWH, Box 268. The BTCJ calculated that it distributed 340984 books and over a million magazines.

Pretoria. Books for the Troops Scheme. 194I. Report on Progress, September 194I. NLSA manuscripts, File MSB 7I/I/7.

Progress report. Books for Troops and Ships Committee. 23 March to 25 May 1945. NLSA manuscripts, File MSB 71/I/8.

Report of the postponed third triennial general meeting of the South African Library Association held at Cape Town from Monday to Wednesday March 18-20, 1940. South African libraries, 8(I): I-I9.

SALA Books for Troops Funds - Correspondence. 19 June 1942. UA, SAILIS Archives, File 2/1/7.

S.A. Libraries have sent army 600000 books. Rand daily mail, 3 July 1943. SANDF Doc, UWH, Box 268.

S.A. Library Association - YMCA Book Committee. Progress Report, October 194I. NLSA manuscripts, File MSB 7I/1/7.

Scheme for Soldiers' Libraries: report for the consideration of the Council of the South African Library Association. 194I. UA, SAILIS Archives, File 2/I/7.

Second Progress Report. Books for the Troops. September 194I. NLSA manuscripts, File MSB 71/1/7.

Servicemen still need books. 1945. SANDF Doc, UWH, Box 268.

650 Gift books for S.A. Troops. 1939. Rand daily mail, 19 October. Also in South African libraries, 7(3): II 3

Special meeting. 26 October 1942. Books for Troops and Ships Committee. NLSA manuscripts, File MSB 7I/I/3.

SA Jnl Libs \& Info Sci 2005, 7I(2) 
Summary of Report on Work of Main Centre Libraries. 18 September 1940. South African Library Association, Pretoria, JPL Strange, File S/Store/Q 027.65.

Third Progress Report. 1942. Books for Troops Committee. NLSA manuscripts, File MSB 71/1/7.

Triggs, M. 2003. Treats, not troops, needed in Iraq. Arnews: Army news service. Available at: http://www4.army.mil/ocpa/ read.php?story_id_key $=5188$ (Accessed March 2004).

Troops Literature Depot. 1918. Cape Times, Wednesday II December: 8.

Turner, W.A. 1939. Public libraries in wartime. Library Association record, 4 I (10): 502-3.

UDF's need of books: special appeal by General Smuts. Cape times, 17 March 1945, NLSA manuscripts, File MSB 7I/I/7.

Vane, M. 1943. Apathy supercharged: a criticism of our war effort. Springs: Springs Advertiser.

Varley, D.H. 1942. Libraries in war-time. Cape libraries, I(2): I. 